\title{
MEASURES FOR HELPING THE MENTALLY RETARDED IN JAPAN
}

\author{
Yasumasa MIKI \\ Asahide Research Institute for the Mentally Retarded, Tokyo
}

Just like in other countries of the world, various plans for helping the mentally retarded are being developed in Japan.

Various agencies under the control of the Ministry of Welfare have undertaken the welfare of the mentally retarded, their education has been under the jurisdiction of the Ministry of Education, their criminal acts the Ministry of Justice, vocational guidance and the employment problems the Ministry of Labour, and needless to say, medical doctors have been responsible for the clinical services for them.

Further, we can point out the valuable contribution of various journalistic agencies in drawing the attention of the public to such problems.

The number of studies of the mentally retarded is gradually increasing among the convention reports in medical sciences, psychology and education, and among the articles which appear in journals of these sciences.

Furthermore, organizations of the parents of the mentally retarded, of the teachers engaged in their education and of the stuffs who belong to the institutions for the mentally retarded have been improved and each publishes a magazine.

The following is the present situation of these various fields.

\section{Welfare Problems}

First of all, let us take welfare problems of the mentally retarded. Welfare works for them have been started by charitable dispositions in Japan same as in other countries and with devoted activities of these philanthropists. Thus in 1891 "Takinogawa School" was founded. In the same year a great earthquake had broken out in the Central Districts of Japan and many people suffered from it. Hearing of the miserable conditions of the orphans at that time, Mr. Ryoichi Ishii, who had been teaching at a certain women's school fetched fourteen orphans, among whom there happened to be an idiot. That is why he founded "Takinogawa School" afterwards. Mr. Ishii went to the United States in $\mathbf{1 8 9 6}$ to study educational methods for the mentally retarded at Fernald School under Mrs. Seguin.

Later in 1909 "Shirakawa School" was founded in Kyoto by Mr. Ryokichi Wakita. In 1916 Mr. Saichi Iwasaki opened "Tohkajuku" in Osaka and in 1919 Mr. Teijiro Kawada founded "Fujikura School" in Ohshima Island: further in 1933 "Yawata School" was opened in Chiba by Mr. Yasuhisa Kubodera. These were all small scaled institutions founded by non-governmental volunteers and supported contributions of the people and a small amount of grant from the Government. Such was the situation in Japan before the World War II and the number of the institutions was thirteen.

In 1946 after the World War Il was over, the Child Welfare Law was enacted following a new democratic Constitution and the nation or a society has been responsible for the welfare of the children. Accordingly, the number of the institutions for the mentally 
retarded has increased year after year and in 1962 it amounted to 163 (1 national, 65 public and 97 private), to which 9,863 children were admitted. The following table shows the process of the increase.

\begin{tabular}{l|cc}
\hline year & the number of institutions & the number of children admitted \\
\hline 1948 & 16 & 716 \\
1950 & 32 & 1,548 \\
1955 & 75 & 4,382 \\
1960 & 128 & 7,681 \\
1962 & 163 & 9,863 \\
\hline
\end{tabular}

Further, you can find 41 training centers ( 38 public and 3 private) where 1,415 children have been attending and receiving the training.

Thus the institutions for the mentally retarded have been improved remarkably after the war not only in the number but also in its quality. While the prewar institutions had simply kept the children, the postwar institutions aim at their rehabilitation, for which vcaotional education and guidance are also taken into consideration.

Further, based upon the Welfare Law of the Mentally Retarded for those above the age of eighteen which was enacted in 1960, various systems such as counselling bureau, itinerating supervisor, training center for the adult mentally retarded, occupational parents system and so on have been at work.

The number of counselling bureaus for the mentally retarded is 46 in 1962, that of itinerating supervisors 437 (full-time 81 , part-time 356), that of adult mentally retarded training centers 25 (19 public and 6 private, in which 1330 and 202 people are taken, respectively) and the number of the mentally retarded entrusted to occupational parents is 423 .

Scope of Education.

Japan had kept in seclusion for a long time until he restored diplomatic relations with foreign countries at the begining of Meiji Period and started the reform of the country. In 1872 "Educational System" was established to improve the education with which Japan had been behind and thus the system of compulsory education started. Since then school education spread remarkably and in 1909 the percentage of school attendance exceeded $98 \%$.

Accordingly, those children who could not keep up with general education were gradually noticed and in 1890 a special class was organized in Matsumoto City of Nagano Prefecture. Later, on based upon the instruction of the Ministry of Education to study special education at teacher training school, special classes were organized at normal schools in Osaka and Tokyo and Heilpadagogik of Germany was also introduced.

The World War I brought Japan prosperity and the Industrial Revolution, which implanted an idea of freedom and equality and also that of emphasizing individual differences and personality in the field of education. Thus the number of special classes has increased. It is difficult to obtain an accurate number of them, but about 200 special classes have been organized in Japan even before the World War II.

The following is the information about the special classes in the City of Tokyo: 


\begin{tabular}{c|ccc}
\hline year & $\begin{array}{l}\text { the number of school } \\
\text { with special classes }\end{array}$ & $\begin{array}{l}\text { the number of } \\
\text { special classes }\end{array}$ & $\begin{array}{c}\text { the number of } \\
\text { children }\end{array}$ \\
\hline 1920 & 2 & 2 & 38 \\
1925 & 20 & 22 & 427 \\
1930 & 27 & 31 & 572 \\
1935 & 25 & 28 & 550 \\
1940 & 28 & 30 & 422 \\
\hline
\end{tabular}

However, as the World War II proceeded, totalitarianism covered education and the number of special classes decreased.

After the war under the new Constitution "The School Education Law" was established in 1947, in which the special education was prescribed. Supervisors in charge of special education were appointed by the Ministry of Education, and workshops in this field were opened in many places and thus the organization of special classes has been proceeded. It was in 1952 when Special Education Section was organized in the Ministry of Education. The same Section investigated into the rate of appearance of the mentally retarded, their progress of study in regular classes, etc. in order to set the standard for diagnosing the mentally retarded and decide the basic policy for their treatment.

Thus the number of special classes has increased year after year and now it amounts to about 4,000 . The following figures show the process of the increase:

\begin{tabular}{l|ccc}
\hline year & elementary school & junior high school & total \\
\hline 1945 & - & - & -19 \\
1950 & 602 & 49 & 651 \\
1955 & 930 & 242 & 2,172 \\
1960 & 1,658 & 769 & 3,427 \\
1962 & 2,908 & 1,159 & 3,867 \\
\hline
\end{tabular}

Besides, we have 31 special schools for the mentally retarded ( 2 school attached to national universities, 7 public, 17 municipla and 5 private), in which over 3,000 children receive the education. The total number of the children admitted to special classes and schools for the mentally retarded estimated in 1962 was 44,380. Since 549,000 children, that is, $3 \%$ of $18,300,000$ school age children under compulsory education, are considered to be mentally retarded, the rate of attendance to special classes is estimated to be about $8 \%$.

Comparing the special education before the war with the same after the war, we can clearly see the difference in quality as well as in quantity.

First of all, special education is now considered as a matter of course in public education and the nation or regional public bodies are responsible for supporting the same financially and further the Ministry of Education plans to raise the rate of their attendance up to $20 \%$ by 1970 .

Secondly, the contents of education have been changed. While the purpose of special education heretofore was to lower the standard and follow up the average children as far as possible by mere repetition method, today's special education aims at fostering the ability for participating in social life, based upon psychological characteristics of the mentally retarded.

We regret to say, however, that education still means 3Rs for many people and even 
many of the special class teachers who have the idea of life centered education, tend to emhasize 3Rs in their practice.

The Ministry of Education is to publish The Course of Study for the education of the mantally retarded in 1963 and to enrich the special education.

The important factors of spreading the education for the mentally retarted are to obtain capable teachers for special classes and to enlighten parents of the mentally retarded and further the society.

We have had an inservice training session for the teachers of special classes every summer for about a week and the courses for the training of these teachers are opened at twenty universities. However, we must add that the increase of the number of special classes is so rapid that regular teachers without special training have to be in charge of many special classes. The teachers of special classes or school are paid 8 to $12 \%$ extra for their services. It is extremely important for the development of special education to train capable teachers.

Understanding of the problem of mental retardation has recently improved among the parents, but since the remnants of the old family system and feudalism still influence the idea of Japanese people who make much of their family line and birth, it is a great burden for them to have a weak-minded child not only in their worries about the child himself but also in those against relatives or neighbours. Consequently they tend to hide such a child and it requires them of a great courage to put a child into a special class. Indeed it is extremely important to educate the parents.

Since the new Constitution has guaranteed the fundamental human rights and also happy and healthy life of the people, and futher it has been proved by the progress of medical science that mental retardation is not so much related to heredity, which is often considered in connection with family line, the idea toward the mentally retarded has greatly changed. Further, through the work of Japanese Parents Association for the Mentally Retarded which was organized in 1952, the understanding of the problem has been deepened. The Association has their head office in Tokyo and affiliated bodies in nearly all prefectures, and their magazine "Parents hand in hand" sells up to 20,000 copies.

Since the education for the mentally retarded aims at their participation in social life, special classes at junior high schools provide the facilities for vocational education such as carpentry, sewing, knitting, embroidering, cooking, washing, ironing, gradening, animal breeding, ceramics, paper works, printing, metal works, bamboo works, etc. Many of

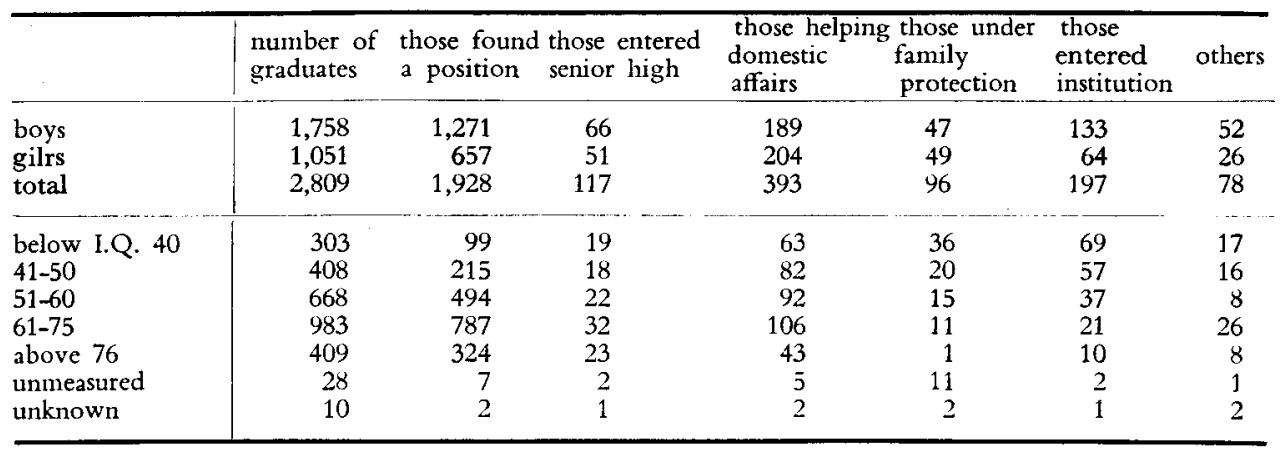


the graduates from special classes have secured suitable job opportunities.

The next table shows the result of the survey on 2809 graduates from special classes of junior high school in 1962, investigated by the Ministry of Education.

The table shows that a considerable number of the graduates from special classes of junior high school participate in social life.

As special classes and schools for the mentally retarded have recently increased in number, the Ministry of Education decided on a policy in 1962 to train severe cases and those who have problems in social adaptability in special, and educate less severe cases in special classes. When the number of special classes and schools increases, it would become possible to organize a class with homogeneously retarded children. At present nearly $80 \%$ of the schools with special classes have only one special class, and many of the rest have 2 or 3 classes at most. We believe that each school should have at least two special classes. The number of the children in a class is shown in the following table:

\begin{tabular}{l|rrrrrrrrrrrrr}
\hline & total & $\begin{array}{c}\text { less } \\
\text { than } \\
9\end{array}$ & 10 & 11 & 12 & 13 & 14 & 15 & $16-19$ & $20-25$ & $\begin{array}{c}\text { more } \\
\text { than } \\
26\end{array}$ \\
\hline $\begin{array}{l}\text { elementary school } \\
\text { junior high school }\end{array}$ & 2,670 & 1,060 & 420 & 333 & 286 & 184 & 157 & 122 & 75 & 28 & 5 \\
\hline
\end{tabular}

The table below shows the I.Q. distribution (in \%) in special classes.

\begin{tabular}{|c|c|c|c|c|c|c|c|c|}
\hline & -40 & $41-50$ & $51-60$ & $61-75$ & $76-$ & unmeasured & unknown & total \\
\hline $\begin{array}{l}\text { clementary school } \\
\text { junior high school }\end{array}$ & $\begin{array}{r}9.1 \\
10.8\end{array}$ & $\begin{array}{l}11.3 \\
15.0\end{array}$ & $\begin{array}{l}17.4 \\
24.4\end{array}$ & $\begin{array}{l}37.4 \\
34.2\end{array}$ & $\begin{array}{l}19.9 \\
12.0\end{array}$ & $\begin{array}{l}3.0 \\
2.4\end{array}$ & $\begin{array}{l}1.9 \\
1.2\end{array}$ & $\begin{array}{l}100 \\
100\end{array}$ \\
\hline
\end{tabular}

You can see that special education of Japan is still on a process of development and not yet nationally homogenized.

Employment Problems

The employment problem of the mentally retarded is under the responsibility of the Ministry of Labour, and it has not yet reached the stage to have a law which prescribes the employment of the mentally retarded or to keep special personnels in charge of such problem. Comparatively well-organized measure have been taken for the employment problems of the physically handicapped, of which we have made use little by little for the same problem of the mentally retarded.

According to the investigation of the Ministry of Education in $1962,38.5 \%$ of the graduates from special classes with a job have got the job through the efforts of special class teachers, $33.7 \%$ through recommendations of an employment security office, $23.7 \%$ by parental connections and $4.1 \%$ through other steps.

Since we have no special agencies for the employment problems of the mentally retarded, special class teachers try hard by themselves to find jobs for their graduates. It may be of some advantage for the special education for the mentally retarded in Japan, however, because thus they try to improve the social ability in real life.

Juvenile Delinquencies

It is often pointed out that a considerable number of the juvenile delinquencies have 
been committed by the mentally retarded. However, the result of some fifteen surveys made during recent fifteen years show the percentage of the mentally retarded among the juvenile delinquents is gradually decreasing: more than $20 \%$ up to around 1955 goes down to less than $10 \%$ after 1957 . This is probably due to the increase of the institutions and special classes for the mentally retarded which provide approprivate cares for them.

In Japan the regional institutes for juvenile correction under the control of the Ministry of Welfare are responsible for helping younger delinquents and misdemeanants to start their life afresh, and reformatories under the control of the Ministry of Justice for those above the age of fourteen. Reformatories are devided into four types, one of which is mainly for the mentally retarded. There are fourteen institutions as such to which 1830 children are admitted. However, we must admit that from the educational point of view they are not cared satisfactorily and since they stay there only for one or two years, they tend to bring troubles into society again due to the insufficient measures for the mental retardation itself during their stay at the institution.

Research and Associations for the Mentally Retarded

Studies of the mentally retarded are reported at the conventions of psychopathology, pediatrics, psychology, education, etc. and also appear in related journals. We have also three important associations for the education and welfare of the mentally retarded.

One is Japanese Parents Association for the Mentally Retarded organized in 1952, which is located in Ohuchi Bldg., Sakuragawa-machi, Shiba Nishikubo, Minato-ku, Tokyo. Mr. Yoshichika Tokugawa takes charge of the chairman.

The second one is Japanese Teachers Association for the Mentally Retarded, headed by Mr. Yasumasa Miki. This research group which consists mainly of special class teachers, started around 1948 and reorganized in 1953 and is now situated in Seicho School for the Mentally Retarded, No. 5, 1-chome, Shimouma, Setagaya-ku, Tokyo.

The third one is "Aigo Kyokai" which is an association of the staffs of the institutions for the mantally retarded organized in 1934. The president is Mr. Etsuzo Wakita and the Association has the office in "Yawata School", No. 492, 3-chome, Bokke, Ichikawa-shi, Chiba.

Yasumasa Miki (三木安正 1911-) Graduated from Tokyo Univ. in 1936. 1938- Fellow, Aiiku Institute for Child Welfare; 1945- Member, Institute for Ed.Ic. Training, Ministry of Education, 1951- Assist. Prof., 1954- Prof. of Educ. and Psychol., Tokyo Univ. 